\title{
Briginal $\mathfrak{O}$ rticleg.
}

\section{AN ACCOUN'T OF DR. 'THADDEUS MACCARTY.}

A NLW INALANI COUNTIRY DOC'TOR OF PRL-REVOLUTIONARY 1)AY'.'

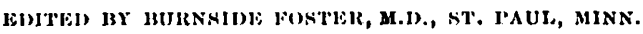

Dr. Thandeus Maccarty, the ollest surviving son of the Rev. 'Thaddeus Macearty, was born in Worcester, Mass., Dec. 19, 1747 (old style). $\Lambda \mathrm{s}$ his father was a country parson with a growing family and small salary, it was wholly out of his power to educate any of his children at a university by any means of his own, but he had an uncle Greenough, the brother of his mother, resident at New Haven, who was in quite aflluent circumstances for those times. 'This uncle generously offered $\mathrm{Mr}$. Macearty that if he would fit one of his sons for college he might be sent to New Haven, board with him, and that he would defiay all the expenses of his education. Mr. Maccarty accordingly hesitated not to accept this kind offer, and his son 'Thaddens was put to his Latin. Noless a man than John Adams, who kept a school in Worcester some portion of the time he was rearling law in the oflice of Colonel Putuan, was one of his first instructors. But according to the doctor's account given long afterwards, this truly great man was not one of the best of school-masters. He used to sit at his desk, the doctor said, nearly all his time, engaged in writing something which the doctor then supposed to be sermons, but as Mr. Arlams was engaged in the study of the law and not the gospel, this was probably a mistake. He seemed when not actually writing absorbed in profound thought and abstracted from everything about him, and he kept his school along by setting one scholar to teach another; this is the doctor's account given forty years afterwards. How far the doctor's preparation to enter college was made at this school or any other school within the town I was never informed, but it was finished in the family of a certain Mr. Iutchinson, a minister of some one of the neighboring towns. Being thus prepared, he proceeded to New Haven and entered the Freshman class of 1762 , and after a residence of four year's took his degree of $\Lambda . B$., and returned to his father's house with the reputation of being one of the best classical and mathematical scholars of his class. The following winter he taught a school either in the town of $W$ ard or that part of Worcester adjoining Ward. In the spring of 1767 , having chosen the science of medicine for a profession for life, he proceeded to the town of Rutland in this county and entered himself a student of medicine and surgery under the auspices of the late Dr. John Frinke, then one of the most eminent physicians in this portion of the country. He had for a companion and fellow-student I)r. Cutler, nfterwards a physician of some note in the town of Rockingham and state of Vermont. How long he continued at Rutland with Dr. Frinke I do not exactly know, but I suppose about three years. The Massachusetts Medical society at this time was not formed; there were therefore no oflicers to examine and license a

I 'This account was written in $1 \leqslant 36$ by I)r. Macenrty's son-In-law, John W. Stlles of Worcester, Mass., nind is liero published for the first timo by Jr. Mncenrty's groat-grent grandion. young physician as in our days. Ijpon the completion of his studies, however, 1)r. Frinke gave him a certificate recommending him in very high terms as fully qualified to commence the practice of physic and surgery. 'The first field of the doctor's labors in his new profession was in the town of Dudley in this county.

On the 25th of July, 1770, he entered into partnership with Dr. Ebenezer Lillie, a physician already in full practice in that town and vicinity. Here the doctor labored three full years, having as much as he conld possibly do both night and day; this was a very fortunate chapter in the doctor's life, for besides the opportunity it afforded of making some money, of which he at: that time stood in great need, what is of vastly more consequence, it gave him at once, by his union with an established physician in full practice, an opportunity to thus fit himself for the field of his future labors. $\Lambda$ t the expiration of the three years he closed his connection with Dr. Lillie and soon afterwards repaired to Fitchburg, and took up his residence there, as he then thought and intended, for life. Here was a field as large and extended as any young man, however ardent and ambitious, could wish to enter. The doctor found himself immediately in full and very laborious practice; there was no physician at that time, himself excepted, in Fitchburg and five other towns adjacent. Doctor Shattuck of Iempleton, the father of the distinguished gentleman of that name, now in Boston, ${ }^{2}$ was the nearest of any note, and he was laboring in a field as large. It is scarce possible at this day of improvement in all things to form any adequate idea of the labors of these men. 'There were no roads anywhere fit to be so named. 'The doctor kept four or five horses, and, having constant calls, kept hoth himself and them in perpetual motion. I have often heard him in after life relate the toils and adventures of this period, and how many narrow escapes he had of broken neck and limb. In one instance, he said, when his horse was in full trot on a winding road through the woods, and in a very dark night, he ran his hend full butt against a tree; this sudden intermption of rapid motion effectually separated man and horse, and prostrated both upon the ground rather more suddenly than either thought desirable. When hearing the doctor relate these toils and dangers of his early life, I little thought that forty years afterwards I should be taxing a worn-ont memory to call them into being again.

In the month of January, 1775 , the doctor was united in mariage to Miss Experience Cowdin, oldest daughter of 'Thomas Cowdin, Ksy., of Fitchburg. This proved a very fortunate and happy event in the doctor's life. She was a woman of good understanding and of a kind and amiable disposition, possessing all the virtues to adorn and render happy that very important relation in human life, the married state. This choice was highly approved by all the doctor's numerous friends and relations, who always held her in the highest estecm, until by an early death she was removed from this to a happier world, lamented and held in affectionate remembrance by all who knew her.

In the spring of this year the smallpox was making fearful ravages, not only in the army, but in 21886. 
all parts of the country. Everybody was exposed, and the doctor, who had not had it, among the rest. Something must be done; although with much diffculty, the doctor finally concluded to leave his family and business at once, go to some hospital and have it. At this time there was a hospital of high repute in Great Barrington, and another in Claverdale in the State of New York, both under the superintendence of a certain Dr. Latham, who managed that terrible disease with great success according to the Suttonian method, then a profound secret, and, for aught $J$ know, is to this day, except to those who purchase the important secret. The doctor lost no time in repairing to Great Barrington, was inoculated and came off victorious, having the disease very lightly. As this was an important affair to the doctor afterwards, perhaps it may not be amiss to say a few words about it, which can best be done in Latham's own language as follows :

"Whereas, William Sutton of Kensiugton Iane, in the County of Surrey, in Eugland, hath found out and discovered a method or art of inoculation for the smallpox, and hath also discovered and prepared eertain medicines, preparatory and effectual in the cure of that distemper, and, whereas the said William Sutton, in order to extend the benefit of this method to $\Lambda$ merica, did, upon certain conditions, take James Iatham into partmership for the carrying on and practising of this said method, art; or mystery, and inoculation with the medicines aforesaid in certain districts in $\Lambda$ meriea, with power to depute under him other persons within said districts under certain terms and conditions," etc.

This James Latham was surgeon to his majesty's Eighth Regiment of Foot, or had been, for so he styles himself, and then resided at Livingston Manor, New York.

Dr. Maccarty got through the disease himself, entered into partnership and Articles of Agreement with Dr. Intham, dated July 24, 1776, for the purpose of establishing a hospital in Fitchburg, and he was thereby duly appointed Dr. Iatham's deputy within that town for the term of twenty-one yenrs, promising and engaging, however, not to practise said art in any other place whatever, beyond the limits of said town, withont a license first lial been oltained in writing from said Latham. Dr. Iatham was to have one half of all moneys received in the work of the business until his portion should amount to three hundred pounds, after which he was to receive one third. Iatham was to furnish the medicines from time to time, ready prepared, but was not to be obliged to disclose or discover to $\mathrm{Dr}$. Maccarty the method, art or mystery of preparing and making up the said medicines or the contents or composition thereof; and Dr. Maccarty on his part solemnly promised and engaged " to render an account every three months of all persons inoculated by him, not to dispose of, or sell any of the medicines or use any other than such as he would receive of said Latham except in case of necessity, and especially not to analyze or otherwise try to discover the composition of the said medicines or permit it to be done by others." In addition to these articles of agreement Dr. Maccarty received from Iatham an extension of his powers and a letter, of which the following is a copy:

Griat Barizington, 24tlı July, 1776. Sir, - During the absence of Dr. Paine, you mily inoculate and attend the natural smallpox in any part of the county of Worcester until his return, and as also inoculate und attend the natural smallpox in Middlesex County until such time as I appoint partners there, or that you hear from me contradieting this lieense and to take what sum you can get from each. I am your most humble servant,

JAS. LATHAM.

It seems from this document that the late Dr. William Paine of Worcester had already been appointed by Latham to treat the natural smallpox in this county, according to the Suttonian method, if not to inoculate, and that being absent, Dr. Maccarty received this additional authority. ${ }^{3}$

'This business being concluded, the doctor lost no time in returning to his family. On his arrival at Fitchburg, an incident occurred, which, without the greatest prudence on his part, might have blasted his hopes and ruined his business if not himself forever. It seems at this period the doctor was strongly suspected by the good people of Fitchburg of Toryism, and the "Committee of Safety" had just had a meeting, and agreed to arrest I)r. Maccarty as soon as he should return, then hourly expected, and subject him to a severe examination, and if not fully satisfied to forthwith, according to the statutes of Judge Lynch, adorn him with a robe of tar and fenthers. Fortunately for the doctor a fast friend of his was in the secret, and was on the watch for the doctor's return. He arrived in the evening about the last of July and was immediately informed by his friend of the whole affair and the discipline prepared for him, and that he might expect to be arrested as soon as his arrival should be known. However, the doctor rested in peace that night. 'The next morning early, the doctor observed Deacon Ebenezer Goodridge, one of the Committee of Safety, riding by, and immediately went out and addressed him thus: "Deacon Goodridge, I got home last evening and have understood that the Committee of Safety have some business and wish to see me. If you will tell me where they meet I will do myself the pleasure of calling on them immediately." 'This open and fearless frankness disarmed the good deacon of all his patriotic wrath, who soon afterwards made a favorable report to his brethren, saying: "The doctor, he believed, was a pretty good man and meant well, that he was a good doctor and they could not do without him, and that he thought they had better admonish him and let him go." So when the doctor met the committee, this favorable speceh of Deacon Goodridge, together with his own prudent management, removed their suspicions in a great degree, so that after a little Whig lecturing the doctor was permitted to depart in pence and escape the tar and feathers.

'The doctor returned to his regular business, and in pursuance of his contract with Latham made. application to the General Court of Sessions of the Peace, agreeably to an act of the General Court then lately passed, and at a special session held at Worcester on the 15th of August, 1776, was duly anthorized "to erect a smallpox hospital in the town of Fitchburg, subject to the orders and regulations of said court." On the 1st of October following the doctor entered into partnership with Dr. Israel $\Lambda$ therton of Lancaster, and in conjunction

"The orletenal documents relating to the business relations bo. tween Latham and J)r. Maccarty were presented by me to the Bos.
ton Medical Library, where they now are. $-\mathbb{B}$. F, 
with him proceded immediately to carry into effect will of Him who disposes all events, and regretted his contract with Latham. $\Lambda$ lospital was erected, by all who knew her.

and all necessary preparations being made, it was soon filled with subjects for inoculation. IIow long it continued in operation, I am not informed, but long enough, as I have heard the doctor sily, to carry through eight hundred persons with the loss of only five by death. This it would seem was good evidence of the goodness and eflicacy of Dr. Siutton's system.

After the termination of the smallpox encern with 1)r. Atherton, Dr. Mitecarty continuer his regular practice in Fitchburg and the neighboring towns without any particular event worthy of motice until the year 1780 , when his father's health being in a declining state he made very frequent visits to him in Irorecster. Indeed, his father could not feel satisficel without seeing him twice a week. 'This took up so much of the dloctor's time that it began sensibly to injure his business. l'eople were continually af ter him, and he was gone to Worcester. Sickness camnol wait, another physician must be had. Dr. Locke, a young physician, had come into town. D). IItskell had settled in Iunenburg, was rising in reputation and afterwards was very distinguished. I)r. Whiton hat taken his stand in Winchendon, and was highly approved. 'These all occupied the ground of 1)r. Maccurty's former labors, and if Dr. Maccarty could not be had, because absent in Worcester, some one of these others could. 'Thus his practice fell away. In this state of things, his father alvised, nay, urged him, to close his concern in Fitchburg and move to Worcester as soon as possible and commence practiee in this town. In an evil hour for him he accepted this advice, and in the month of Jume, 1781, returned to his native place, and although he did, a portion of the time he remained here, a tolerably fair business, it never was anything compared to what he had left at litchburg. In a few years he buried both his parents, his mother dying Dec. 28 , 1783 , and his father, worn out by a long sickness, July 20, 178.4. The doctor mitil this time had lived about a mile out of the street, which was a great inconvenience, and indeed an injury to his business, and on the death of his father he moved into his house on the soutl side of the common. After his removal the doctor's business rather improved for a season. On the 1 st of .June, 1785, he was elected a fellow of the Massachusetts Medical Society. Nothing from this time worthy of note occurred that I know of, except the formation of the Second Religious Society in Worcester, in which the doctor was heart and hand engaged; he was a great admirer and fast friend of I)r. Bancroft, nor did he lose his attachment and respect for that gentleman years afterwards, when the inhabitant of another State. I have of ten heard him mention Dr. Bancroft as the only minister in this vicinity who preached the gospel according to his understanding. 'This was forty year's ago, when I had never seen Dr. Bancroft, and never expected to.

In Jamuary, 1789, the doctor was infortumate enougl to lose his excellent wife, the greatest of all possible losses to him; her health had been declining for some time, and on the 24 th of this month she took her departure from this scene of trouble and suffering with perfect resignation to the
At this time also the doctor's own health was in a feeble and uncertain state; he was ill able to attend to any business, nor was he free from pecuniary embarrassments. His two brothers, Nathaniel and William, were engaged in trade at Petersham and they advised the doctor to give up his profession at once, as ill suited to his poor state of health, or any chance of recovery, and to go into trate, and they recommended Keene in the State of New Irampshire as a suitable place for that purpose. 'This advice prevaled, and in .June, 1789, the doctor once more broke up his whole establishment and translated himself to keeue and took his stand behind the counter, a place for which he was poorly qualified and where he always disliked to be. The doctor at this time had three children, a daughter and two sons. Upon breaking up at Worcester, these were distributed among his connections. The daughter went to Fitchburg, and resided with her mother's connections; his two brothers adopted the two sons, who hat been named for them. William Macearty this spring removed from Petersham to Boston and took the doctor's oldest son William with him, and Nathaniel Maccarty took the roungest son to l'etersham, a little boy of aboui three years; thus they appear to be happily disposed of. liut the doctor was cloomed to farther trials; his little son in Petersham died in about a year very sudklenly of the croup, and before the doctor conlid possibly arrive there, and his brother William after a long and tedions illness died at Billerica in the summer of 1791. 'The doctor's eldest soll thus lost his home and followed his father to keene.

In lieene the doctor continued his mercuntile business, practising physic occasionally, which, however, gradually increased as he became more known; he was of ten called in to advise the attending physician and not infrequently at a considerable distance in many of the neighboring towns. The winter of 1791 he spent in 13oston attending his brother William in his last sickness. Here he became acquainted with the late Dr. Jeffries, who had attended his brother. 'This acquaintance led to a correspondence which was continued long afterwards "y)on the various suljects connected with medical science. In the spring of 1793 the doctor was again called upon to try the eflicacy of his old friend, I)r. Sutton's secret medicines. 'The smallpox had broken out the year before, and was in all parts of the country. Dr. Hastings had established a hospital in Charlestown, N. H., and not being acquainted with the disense called upon 1)r. Maccarly to assist him. The doetor repaired to Charlestown and stayed some time, long enough to assist in carrying through a large class without the loss of a patient. Some years afterwards he had a similar application in Keene with a like success; none died, except two or three who took the discase the natural way.

In the year 1796 , if I mistake not, the doctor was called to a new, and until then unlieard of, mode of curing diseases; it was sulliciently secret for Dr. Sutton himself and for a while as chlicncious. I mean nothing more or less than the celebrated tractors of Dr. Elisha Perkins. He called on Dr. Maccarty to obtain his aid in introducing them into that part of 
the county, to induce him, if possible, to make use of them professionally, and accept of a general arency in the sale of those marvelous things. I happened to be present when Dr. Perkins arrived, heard him state the object of his visit, saw the little magic pointers opened, heard him explain their use and mode of application, the wonders they had done, the greater wonders they wonld do, the principle on which they acted, in which he took care, however, to conceal it, and I never shall forget the concluding remarks of all this great learning. Ite expected opposition, he said, from ignorance, bigotry and prejudice, but the time would come when it would be acknowledged by all that the tractors were the greatest discovery of modern times, and raised us one step nearer to Him who knoweth all things; these may not be his exact words, but they are substantially. I stood with amazement and verily thought thit if all Dr. Perkins said was true, the gods had come down to us in the likeness of men, as the good people of lystra did on a more important occasion. Ir. Perkins had all the appearance of having full confidence in the complete efficacy of the tractors. Dr. Maccarty was apparently as much amazed as I was, they were entirely new to him and indeed he knew not what to say, and therefore said but little. I went to my business and left the doctors together, and when I came home at night Dr. Maccarty informed me that he had accepted the agrency and had twenty or thirty sets of tractors left for sale at $\$ 20.0()$ per set, he to return $\$ 16.00$ for all he should sell, and Dr. Perkins had made Dr. Maccarty a present of one set. A pompous advertisement was prepared, I believe, beforchand, setting forth their wonderful power, and it was not long before the tractors rose into marvelous reputation. 1$) r$. Maccarty had abundance of employment, some came and purchased them, particularly all the doctors in the vicinity. Some came for the doctor to go and use them. Great cures were wrought; the very chiefest apostle of animal magnetism could not do more. All the good woinen, old and young, whose nerves were a little disturbed, came and were healed, or fancied themselves so, which was just as well. Many a time when Dr. Maccarty returned from using them, and related what he had dome and seen, he appeared evidently to have worked himself into faith, and this delusion continued, if I remember right, as much as two years, without much abatement. 'The doctor sold all his tractor's, and afterwards received fifty sets more; how miny of these he sold I never kinew, as not, long afterwards I left his employment. From a letter from I)r. Perkins to Dr. Maccarty now lying before me, dated Plainfield, Dec. 14, 1797, I make the following extract: "We have continually increasing testimonies, and from respectable quarters of the efficacy of the tractors. 'Their general ellicacy is now established to the confusion of the envions, the ignorant and the bigoted, who always have and ever will oppose usefui discoveries and improvements." But in about two years from their introduction into Keene, the tractors began to lose ground, and in the course of another year sank with remediless disgrace. Christopher Caustic, however, has saved them from oblivion.

‘Terrible Tractorntion, a l'octical Pettion arnlnst, Galvanlzing Trumpery and the P'orkinistic Institution, by Christopher Catus. tic, M.D., LL.D., Ass., Londion, 1803.
In February, 1799, I)r. Maccarty was appointed a justice of the peace for the connty of Cheshire, ancl in February, 1802, a justice of the Quorum. 'This circumstance is perhaps latrdly worth mentioning, such oflices are now so common and so cheap, but it wis an important thing to the doctor, as he did a great deal of profitable lusiness in that capacity. IIe was also one of the Board of Selectmen, and chairman of that body some years.

The doctor had been preparing his only son William for a collegiate elucation for some years, and in 17 !) 6 he repaired to Hanover with him at the general commencement, and his son was entered in the Freshman class, but being so young it was not the roctor's purpose to keep him there under another year. I3ut, alas, how vain are all human calculations built on future and uncertain events : 'The doctor was doomed once more to disappointment in all that lay nearest his heart; this son, this only son, this only male child surviving of the whole race, was soon to be gone. He sickenerl in the fall, grew weaker and weaker, but without pain, and expired on the 4 th of February, 1797, of a diabetes, in the fourteenth year of his age. This event affected the doctor more than all others since I had known him.

l'erhaps before I close this imperfect sketch I ought to say something of the doctor's theological and religious sentiments. But this is the most diflieult part of the whole. I heard him converse for four years on religious subjects more than on all other subjects put together, and yet it was as diflicult; to ascertain what he really belicved as to find out the longitude of perpetual motion. I have already inentioned what he said of Dr. Bancroft, but when that is compared with what I have heard him say on many other occasions it would secm to he the man he loved quite as much as any particular systiem of doctrines. I don't know but I do wrong to say anything about it. I know his friencls and particularly Mr. West, his hrother-in-law, considered him a deist. But the doetor never acknowledger himself one to my knowledge. IIe mentioned, however, several times that in his younger days he had been inuch conversant with deistical writers, which gave his gool father much uneasiness. He used to inention Hobbes, Spinoza, I)r. 'Tindall and $\Lambda$ nnat as anthors he had read. But he had no such books in his own library, and I never saw a deistical book in his house or knew him to read one all the time I lived with him, nor dicl l ever hear him defend such sentiments. The doctor was very familiar with the scriptures, and very fond of controversy.

He knew all the clergymen in the vicinity and they often called upon him, and rarely separated without, a dispute, but they were always conducted with good temper, and I never saw any feverish excitement on either side. But the doctor could argue on all sides and with equal force, and he did this so of ten that I ralely felt sure that he was really of the opinion which he defended. But in all his discussions it was always taken for granted that the scriptures were true in some sense. The doctor read Greek and Jatin with the greatest facility, and his knowledge of Greek was always one ehief dependence in his disputes with the ministry; very few in that neighborhood knew much Greek, from long disuse it had faded from the mind. When, therefore, a text 
was produced which the doctor could not evade in any other way, he would contend for a difierent translation, quote the Greek and renter for himself. This was often decisive, for it would silence if not convince. There was one elergyman in the vieinity whom the doctor highly respected and who was really an able man, the Rev. Mr. Ciodelard of Swansey, and they rarely parted without an oral combat. I ivill just briefly refer to one of these, and with it finish this subject. 'The question was the eternity of future punishment. Mr. (iocklard was, of eourse, for the allimative, and the doctor took the other sidle. Mr. Goddard quoted many texts which he supposed supported his position, two of which I will mention, Matthew, chap). 26, v. 24 : "It had been good for that man if he had not heen born," that is, Judas. Mr. Codkard contended that if after ever so long and severe a punishment happiness were then to eommence, as it would continue forever, it conld not be true, that in such case it be better for Jurlas not to have been born, for he considered existence so great a blessing that no rational man wotald refuse it, though subject to ages of sultering, if eternal happiness was to follow. 'The dochor fully admitted this consequence, but he contended that the verse was improperly rendered and the sense perverted or destroyed by reversing the order of the words in the Greek text, in the translation, and that it should be rendered thus: "It had been goorl for him if that man had not been born," and that as "the son of man" was the last antecedent before " him," it cridently referred to" him," and then the sense would be, "It would have been good for the son of man if Judas had not been born," for then he would not have betrayed him, etc.; and this construction the doctor said was supported by the prayer " that if it were possible that cup might pass away from him," etc. Mr. Goddard also quoted Acts, chiap. 1, v. 25 : "'That he may take part of this ministry and apostleship from which Juklas by transgression fell that he might go to his own place." Here the doctor was reandy with a new translation, the last clanse of the verse, he said, was evidently erroneons and that the true meaning of the Greek was utterly clestroyed. The real meaning of it was, he sidid, not that .Juclas should go to his own place, but that the new apostle should take Judas' place in the ministry, that is, "go into his place," and this correction I really think the doctor was serious in, whatever he was in the other, for I heard him mention it on several other oexasions.

In the month of June, 1802, the doetor came to 'Templeton to visit my family, and likewise visited his brother at l'eterslian, but he said to me on the morning of his departure, "I am going to die." $\Lambda$ few weeks afterwards I visited him at lieene. I found bim reading the Septuarint version of the scriptures; he told me he had been engraged in it a whole year, and had been eritically comparing it with the English version. IIe mate many observations upon the various readings, and the difference in the sense of many passages in the tiwo versions, as compared with each other. One of these may be mentioned, as it is of ten quoted and relied on for the establishment of a particular doctrine, hat no corresponding words in the Septnagint, but were entirely wanting. 'The doctor said more mon the subject of religion, seriation, and upon its greneral importance, than I had ever heard from his lips before, and he finally concluded by saying he "was sorry he had disputed so much about it."

I visited the doctor again in September and found he had greatly altered; that hereditary disease which has allicted all his family in some form, and which some of them have ealled the gont and some have not known what to atl it, had fixed itself "upon his lungs, and was fast wasting him away. Still he was able to do business, and as the settlement of his concerns would, he knew, eventually devolve on me, he gave a minute explanation of everything which he thought would be otherwise unintelligible to me, pointed out how he would have them adjusted and especially in some settlements where small mistakes had been made and several sums were due from him to others which no mortal but he could ever know. He pointed them all out and gave me strict injunctions that they should all be carefully rectified. From this time his health rapidly declined, and the last few weeks he was confined to his bed. He continued wasting, but without much pain, until Saturday night the 21 st of November, $180 \%$, when he elosed the, -

\section{"Iast seene of all,}

'Ilat ends this strange, eventful history."

'The doctor left but one child, a daughter, who was maried in November, 1801. She has two children only, one of them was married in 1828 and has three. 'Thus, although the Rev. 'Phaddeus Maccarty had a very large family, even fifteen children, there now survive of all his posterity only one arandehild, two great-igrandehildren and three greatgreat-grandehildren.

"Ijike leaves on trees the race of man is found

Now green in youth, now withering on the ground;

Another race the following spring supplies,

'I'hey fall suceessive and successive rise;

So generations in their eourse decay ;

So flourish these when those are passed away."

\section{IILOMA ARBORESCENS.}

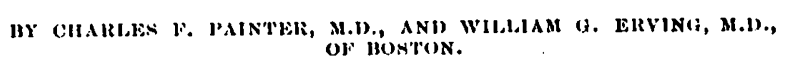
From the Orthopealic (linic of the Curney Hospital.

Tus occurrence of fatty growths in the joints is not very uncommon, thongh comparatively few have attracted enough attention to merit publication. 'Tley have usually been associated with the existence of tuberculosis or arthritis deformans. 'They occur as overgrowths of the synovial villi of the joint or as true lipomata' that have pushed in from the subserous fat as the result of laceration of the fibrous capsule.

As more cases are being studied, it becomes evident that the etiology is not as limited as was at first supposed. Many conditions may cause the hypertrophy of fringes. Under some circumstances the result is a general villous enlargement, and under others it is confined to one or at most a very few villi. The knee joint is the one most commonly affected, though others are not exempt. In this series the eases are all operative, and have come under observation during the past year.

'The seven cases here to be reported in detail are istleda (Beltrng. f. Killn. Chir., Xv1, p. 1896) reports twelve cases of true llpomin in the joints. 